\title{
The Causal Relationship between the Bond Market Development and Economic Growth in Africa: Case Study of South Africa ${ }^{1}$
}

\author{
Kapingura $F$. \\ University of Fort Hare, East London Campus \\ Makhetha-Kosi P. \\ University of Fort Hare, East London Campus
}

\section{Doi:10.5901/mjss.2014.v5n3p126}

\begin{abstract}
The paper empirically examines the causal relationship between bond market development and economic growth in Africa with South Africa as a case study over a period from 1995 to 2012. Quarterly data applying the Engle Granger cointegration method and the pairwise granger causality test was used. Empirical results reveal that there is a relationship between economic activity and bond market capitalization. Our results imply that African governments should put in place policies which will promote the development of the bond market as one of the ways to mobilise domestic resources and promote economic growth.
\end{abstract}

Keywords: Bond market; Economic growth, Africa; South Africa; Engle Granger Cointegration

\section{Introduction}

A number of studies indicate that African countries have lagged behind in terms of growth when compared with other regions. There are a number of reasons attributed to this predicament. The 2009 NEPAD-OECD African Investment Initiative on deepening African Financial Markets for Growth and Investment indicates that African countries have largely relied on commodity prices to support growth, a channel which is highly vulnerable to a downturn as witnessed during the Global financial crisis. At the height of the crisis, African economies witnessed a collapse of export revenues due to the decline in the world demand for minerals and fossil resources.

The report further suggests that, of importance to many African countries is to channel existing resources to productive investments so as to stimulate growth in the continent and one of the ways to achieve this is the development of the capital market. A well-functioning and efficient domestic bond market will guarantee greater diversification of longterm financing and improve resource allocation into domestic investments. This will enable African countries to access long-term debt in local currency thereby providing much-needed financing for the constantly growing housing and infrastructure needs. This is imperative because most African countries are unable to access international capital markets and are faced with a likely decrease in aid financing in the face of a financial crisis as witnessed during the global financial crisis (The African Financial Markets Initiative (AFMI), 2008).

However, bond markets in many African countries are largely underdeveloped with corporate bond markets nonexistent or in their infancy (AFMI), 2008). Also it is important to note that in most African countries the public sector dominates debt issuance, mainly with debt instruments of very short tenor and activities focused on the domestic primary market with limited secondary trading. As of the end-2006, 74 percent of the African countries issued treasury bills while only 49 percent of the countries issued longer-dated government securities. Although several countries have listed the bonds on the stock exchange, secondary market trading remains virtually nonexistent due to the "buy and hold" strategy of domestic banks who hold the bulk (about 70 percent) of the debt due, in part due to the limited lending opportunities and also due to some prudential requirements like liquid asset ratios in some countries that require banks to hold a certain amount of their assets in government-issued paper (AFMI, 2008).

In light of the above, the study seeks to achieve three objectives. Firstly it outlines the current situation of bond markets in Africa. Secondly, it discusses and estimates the relationship between bond market and economic growth in South Africa. Finally, based on the empirical results it offers policy recommendations on the growth of the bond market

1 The first version of the paper was presented at the 10th African Finance Journal Conference (15-16 May 2013) 
and economic growth in Africa. The rationale behind using South Africa lies in that the South African bond market is well developed and efficient as compared to many bond markets in Africa.

The study is structured as follows: Following section 1 which is the introduction, section two looks at the overview of the development of the bond market in Africa; Section three reviews relevant literature; Section four looks at the methodology and estimation techniques; whilst section five focuses on interpretation and conclusion.

\section{Overview of the South African Bond Market}

A study by Mu, Phelps and Stotsky (2013) shows that bond markets in many African countries are at a nascent stage of development with market capitalization of both the government bond market and corporate bond market being much lower as compared to those of other emerging and advanced countries. The study further shows that government bond market capitalization as a percentage of GDP was 14.8 percent in 2010 which is far less as compared to the Asian, Latin America and Central Europe as illustrated in table 1.

Table 1: Bond Market Capitalization Comparison, 2010

\begin{tabular}{|c|c|c|c|c|c|}
\hline \multirow[b]{2}{*}{ Region } & \multirow[b]{2}{*}{ Country } & \multicolumn{2}{|c|}{$\begin{array}{l}\text { Market Capitalization } \\
\text { (percentage of GDP) }\end{array}$} & \multicolumn{2}{|c|}{$\begin{array}{l}\text { Contribution to } \\
\text { Total Domestic } \\
\text { Debt (percent) }\end{array}$} \\
\hline & & Govt & Corp & Govt & Corp \\
\hline \multirow[t]{9}{*}{ Africa } & All & 14.8 & 1.8 & 89.2 & 10.8 \\
\hline & South Africa & 31.2 & 20.0 & 60.9 & 39.1 \\
\hline & All excluding SA & 14.2 & 1.3 & 91.8 & 8.2 \\
\hline & CEMAC & 10.5 & 0.7 & 93.8 & 6.3 \\
\hline & WAEMU & 14.1 & 2.3 & 86.0 & 14.0 \\
\hline & Oil exporters & 7.7 & 1.1 & 87.5 & 12.5 \\
\hline & Fragile countries & 18.4 & 1.2 & 93.9 & 6.1 \\
\hline & Low income & 15.3 & 1.1 & 93.3 & 6.7 \\
\hline & Middle income & 15.1 & 3.5 & 81.2 & 18.8 \\
\hline \multirow[t]{5}{*}{ Asia } & China & 27.3 & 22.8 & 54.5 & 45.5 \\
\hline & Hong Kong & 35.9 & 13.8 & 72.2 & 27.8 \\
\hline & Malaysia & 57.3 & 57.0 & 50.2 & 49.8 \\
\hline & South Korea & 43.8 & 59.5 & 42.4 & 57.6 \\
\hline & Thailand & 50.5 & 12.8 & 79.7 & 20.3 \\
\hline \multirow[t]{4}{*}{ Latin America } & Argentina & 13.3 & 2.6 & 83.7 & 16.3 \\
\hline & Brazil & 39.4 & 22.7 & 63.4 & 36.6 \\
\hline & Chile & 13.1 & 17.1 & 43.5 & 56.5 \\
\hline & Mexico & 22.6 & 17.1 & 56.9 & 43.1 \\
\hline \multirow[t]{3}{*}{ Central Europe } & Czech Republic & 23.3 & 11.2 & 67.5 & 32.5 \\
\hline & Hungary & 57.3 & 7.0 & 89.1 & 10.9 \\
\hline & Poland & 42.6 & 1.8 & 95.9 & 4.1 \\
\hline
\end{tabular}

Source: Mu et al (2013)

As indicated in table 1, the disparity between Africa and other regions is wide when it comes to the corporate bond market. In 2010 corporate bonds capitalization as a percentage of GDP was 1.8 which is far less as compared to those of other countries in other regions.

Also, it is important to note that where the market is thriving, it is mostly the government bond market. As shown in table 1, government bond as a share of total market capitalization stood at 89.2 percent compared to corporate bonds which were 10.2 percent. This has implication for the participation of investors in the market. Van Zyl et al (2009:302) suggest that an environment where only government bonds are available places a limit to the availability of bonds of a wide range of maturities thus affecting investor participation since availability of bonds with a wide range of maturities enhances the establishment of effective derivative markets which enables participants in the economy to hedge their risks effectively and thus promote deeper markets. Further, if the government bond market is particularly large compared to the demand for investment vehicles, it is argued that public debt will crowd out private debt.

The African Development Bank (AfDB, 2011), report further shows that debt markets in Africa lack institutional and operational infrastructure because of low levels of liquidity, narrow investor base, short maturities and high borrowing costs. This has led to loss of competitiveness and breadth of financial products available on the market, affecting the development of the market.

However, despite the current state of the capital markets in Africa, there has been considerable effort to develop 
the capital markets in Africa. The AFMI (2008), shows that there has been long-term advice and training on government debt issuance and management in most African states. Also, there has been support from donors supporting both the development of the government and corporate debt markets through identifying and lowering market risks, volatilities and uncertainties. These will likely attract many investors and hence deepen the bond markets in Africa.

There has also been an initiative to deepen the capital markets in Africa through the creation of regional markets. In the East African Community (EAC) there has been initiatives to link national securities markets through an integrated system, thus increasing visibility of the market and increasing access to trading platforms across the region for dealers in the market (AFMI, 2008). In the SADC region the AFMI report shows that the Capital Markets Development Committee $(\mathrm{CMDC})$ was formulated to integrate the capital markets in the region.

\section{Review of Relevant Literature}

Examining the impact of the bond market on economic growth is an area which is still at its infancy, possibly because the market has been an insignificant portion of the financial markets in Africa. Mostly, studies in this area have focused on either the impact of the banking sector or the stock market on economic growth (Easterly and Levine, 1997; Harris, 1997; Beck, 2003; Dailami and Atkin, 1990) and less attention has been paid to the impact of the bond market on economic growth.

Of the available studies, Fink, Haiss and Hristoforova (2003) examined the causality between the bond market and economic growth in ten countries and obtained mixed results. In seven of the ten countries, the authors found evidence of uni-directional causality in 7 of the 10 countries, in which the causality was strong in 5 of the 10 countries (Switzerland, Austria, UK, Germany and the USA). There was evidence of bi-directional causality in three of the ten countries suggesting that there is interdependence between the two variables. However the link from bond market to economic growth was found to be more robust. This is consistent with Abbas and Christensen (2007) who found that bond market development contributes positively to economic growth in developing countries.

In the same vein, Said (2012) examined the relationship between East Asian debt markets and economic growth for the period 2002 to 2009. The author considered three types of debts, domestic public debt, foreign debt and private debt. Their empirical results revealed that at regional level both private and public debt contributes to economic growth. However at country level the results were not the same. In South Korea there was evidence of both public and foreign debt contributing to economic growth, whilst in countries such as China and Hong Kong only public debt was found to be significantly influencing economic growth.

The other available studies which have been done in this area have not exactly examined the relationship between the bond market and economic growth directly but rather have focused on the impact of the yield curve which has its genesis in the bond market, and how it influences economic growth. Of the studies in that area, Harvey (1989) examined the extent to which the US economy can be forecasted using the yield curve for the period $1953-1989$ and empirical results revealed that yield-curve based measures can explain more that $30 \%$ of the variation in economic activity as compared to the stock market which accounts to about $5 \%$ level only. In the same vein, the author in forecasting the German economic crisis found that bond market related models performed better in forecasting economic growth in many of the research institutes in which it was employed. In addition, predictions from such models predicted the business cycles better during the period of study.

In consonance with Harvey $(1989,1991)$, Ahrens (2002) examined the extent to which the term structure can be a leading indicator of recessions for eight OECD countries for the period from 1970 to 1996 utilizing monthly data employing a simple Univariate model. Empirical results revealed that the term structure is a good indicator of a recession. In addition, in stressing the importance of the corporate bond market, G.de Bondt and August (2002) revealed that the corporate bond spreads lead real economic activity.

In another view, Gambler (1996) in establishing the determinants of the yield curve in the USA for the period 1955 to 1956 found out that changes in interest rates have a significant effect on the effectiveness of the yield curve as it would change its effectiveness when the Fed alters the rate.

In Africa, Odetayo and Sajuyigbe (2012) investigated the impact of capital markets on economic growth and development in Nigeria between 1990 and 2011 employing the Ordinary least squares (OLS) econometric technique to test whether the capital market has impacted the GDP of Nigeria. Empirical results revealed that stock issues, value of stocks and total listed of equities and government bonds jointly have a positive significant impact on the Nigerian economy. In addition, Kapalo and Adaramola (2012) analysed the impact of the capital markets on economic growth in Nigeria for the same period employing the Johansen co-integration and Granger causality tests. Empirical results 
revealed that there is a long run relationship between capital markets and economic growth. The same result was also found by Manna, Owino, and Mutai (2008) who analysed the development of public domestic debt and its impact on the Kenyan economy between the period 1996 and 2007. Using the modified barro growth including a domestic debt variable the results revealed that domestic debt expansion had a positive but insignificant effect on economic growth during period.

\section{Methodology}

In examining the impact of the bond market on economic growth the study will benefit from the work of Fink et al (2003). The authors state that real capital stock growth theoretically might be used as an intermediary variable between financial markets and GDP growth. The model to be used in the study is of the form:

$$
Y_{t}=\beta_{1}+\beta_{2} B_{t}+u_{t}
$$

where $y_{t}$ is the measure of economic activity $B_{t}$ is the measure of the bond market capitalisation and $u_{t}$ is the error term which is assumed to be white noise.

Based on the model, cointegration tests will be conducted to check if there is a long-term relationship between the two variables. As in the case of Fink et al (2003) the study will utilise the Engle and Granger single-equation based twostep approach to test if the two variables are cointegrated. Fink et al highlights that the alternative to the Engle and Granger is the Johansen cointegration test, which is more useful when analysing interaction between more than two variables. The authors reviewing the work of Gonzalo and Lee (1998) argues that the Johansen LR test tend to find spurious cointegration with probability asymptotically approaching one when variables with long-memory properties and trend behaviour are involved that are not distinguishable from pure I(1) via standard unit root tests and when the variables are non-stationery with a singular or near singular error covariance matrix.

In addition, when the Johansen cointegration procedure is used to analyse cointegration relations among variables with deterministic linear trends in which there is no cointegration, the LR test is said to be diverging and the null hypothesis is wrongly rejected. On the other hand, the EG test is arguably not sensitive to incorrect modelling of such components. Also, Haug (1996) argues that when the regressors are exogenous, the ADF test performs best as compared to the Johansen maximum eigenvalue statistic.

The following regressions will be conducted:

$$
\begin{aligned}
& y_{t}=\beta_{0}+\beta_{1} b_{t}+e_{t} \\
& b_{t}=\vartheta_{0}+\vartheta_{1} y_{t}+e_{t}
\end{aligned}
$$

Where $y_{t}$,is the log of the level of real economic activity measured by the Gross Domestic Product (GDP), and

$b_{t}$ being the size of the bond market proxied by the outstanding amount of debt securities issued by the central government. This is contrary to Fink et al who considered the aggregate of both the government bond and the corporate bond. In our case we take into account that the government bonds are the most active in the bond markets in Africa.

However, the first step in our analysis is to determine the order of integration of our variables. This will be done by carrying out stationarity tests. Gujarati (2003) suggest that a stationary stochastic process implies that the mean and variance are constant overtime, and the covariance between two periods depends only on the lag between the two time periods and not the actual time at which the covariance is computed. This implies therefore that a non-stationary time series will have a varying mean or varying variance or both.

The statistical and time series properties of the data set were first carried out using the Augmented Dickey-Fuller (ADF) and Phillips-Perron (PP) to test for unit root. Mallik and Choudhry (2001) and Ahmed and Mortaza (2005) point out that the PP test can properly distinguish between stationary and non-stationary time series with high degree of autocorrelation and presence of structural break.

\section{Empirical Results and Conclusion}

Time series properties of the data were carefully evaluated through the Augmented Dickey Fuller (ADF) and Phillip-Peron (PP) tests and the results are reported in tables 6.1 and 6.2 below: 
Table 6.1: Unit Roots Tests: Level Series

\begin{tabular}{|c|c|c|c|c|c|c|}
\hline & \multicolumn{3}{|c|}{ Augmented Dickey Fuller (PP) } & \multicolumn{3}{c|}{ Phillips Perron (PP) } \\
\hline Variable & Intercept & Intercept and Trend & None & Intercept & Intercept and trend & None \\
\hline Igdp & -1.569784 & -2.275464 & 3.427566 & -1.368935 & -2.407554 & 6.576668 \\
\hline Ibonds & -0.475339 & -1.757112 & 2.693066 & -0.450619 & -1.397028 & 5.960482 \\
\hline
\end{tabular}

Notes: ${ }^{* \star}$ stationary at $1 \%$ leve of significance, ${ }^{* \star}$ stationary at $5 \%$ level of significance, ${ }^{*}$ stationary at $10 \%$ level of significance

Table 6.2: Unit Root test: First Difference

\begin{tabular}{|c|c|c|c|c|c|c|}
\hline & \multicolumn{3}{|c|}{ Augmented Dickey Fuller (PP) } & \multicolumn{3}{c|}{ Phillips Perron (PP) } \\
\hline Variable & Intercept & Intercept and Trend & None & Intercept & Intercept and Trend & None \\
\hline Igdp & $-4.638937^{\star \star \star}$ & $-4.608178^{\star \star \star}$ & $-2.771314^{\star \star}$ & $-4.557837^{\star \star \star}$ & $-4.529855^{\star \star \star}$ & $-2.534998^{\star \star}$ \\
\hline Ibonds & $-3.392814^{\star \star}$ & $-3.362883^{\star \star}$ & $-2.389084^{\star \star}$ & $-3.341280^{\star \star \star}$ & $-3.312663^{\star \star \star}$ & $-2.982964^{\star \star}$ \\
\hline
\end{tabular}

Notes: ${ }^{* \star}$ stationary at $1 \%$ leve of significance, ${ }^{* \star}$ stationary at $5 \%$ level of significance, ${ }^{*}$ stationary at $10 \%$ level of significance

The results show that all variables are non-stationary at their levels. The variables were tested for stationarity at first differences. The results indicated that both variables are stationary. The results confirmed therefore that differencing once was all that was required to bring these variables to stationarity at all levels of significance. This suggests that our variables are integrated of order one I(1). Having established the order of integration, cointegration tests were conducted according to the ADF test on the residuals and the results are shown in table 6.3 block A.

Table 6.3: OLS test for cointegration and the Error Correction model (ECM)

\begin{tabular}{|c|c|c|c|c|}
\hline \multicolumn{2}{|c|}{ Block A } & \multicolumn{3}{c|}{ Error Correction Model } \\
\hline DV & ADF Residual test & Residual term & $\mathrm{R}^{2}$ \\
\hline Ibond & $-2.289439^{\star *}$ & $-205981^{\star *}$ & $\begin{array}{c}0.409553 \text { lgdp } \\
{[2.197269]^{\star \star}}\end{array}$ & 0.75 \\
\hline Igdp & $-2.081860^{\star *}$ & $-2.763761^{\star \star *}$ & $\begin{array}{c}0.245959 \mid \mathrm{bonds} \\
{[7.223513]^{\star \star *}}\end{array}$ & 0.76 \\
\hline
\end{tabular}

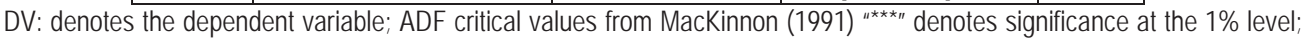
"**" at $5 \%$, ,*" at $10 \%$

As illustrated in block A, the ADF test rejects the null hypothesis of non-stationarity in South Africa for the period under review. Thus there is a common equilibrium convergence between the bond market capitalization and real GDP in South Africa.

Having established the presence of cointegration, the Error Correction Model (ECM) was estimated and the results show that the EC-term is statistically significant at $5 \%$ level. This shows that in South Africa economic growth as measured by GDP and bond market capitalization adjust to the long-run equilibrium state. Our results corroborate the findings of Fink et al (2002) for Japan, Italy, and Finland, Said (2012) for China and Hong Kong. This is not surprising since in South Africa more than fifty percent are public debts.

Pairwise Granger causality tests were conducted to establish the direction of causality between GDP and bond market capitalisation. The results are illustrated in table 6.4.

Table 6.4: Pairwise Granger Causality tests

\begin{tabular}{|l|}
\hline Null hypotheses F-statistic Prob \\
\hline Igdp does not granger cause lbonds $2.721250 .0774^{*}$ \\
\hline Ibonds does not granger cause lgdp $3.150330 .0531^{*}$ \\
\hline "***" indicates significance at 1\%; "**" $5 \%$ and "*" $1 \%$
\end{tabular}

As shown in table 6.4, there is bi-directional causality between GDP and bond market capitalization with the causality from bond market to GDP being stronger as compared to the reverse causality even though both are significant at $10 \%$ level. This result is again consistent with Fink et al (2003) in which the authors found the presence of the supply-leading hypothesis as well as Kapalo and Adaramola (2012) on their study of the Nigerian economy. However in our case there 
is also evidence of the demand-leading hypothesis though at a weaker level.

\section{Conclusion}

The study has analysed the relationship between the bond market and economic growth in Africa, using South Africa as a case study employing the Engle Granger method for analysing the long-run relationship between the two variables. Empirical results show evidence of cointegration. The pairwise Granger causality test was also constructed and evidence of bi-directional causality was established with causality from bond market to economic growth being stronger. Therefore our analysis supports the hypothesis that real economic activity measured by GDP is influenced by development of the bond market. As one of the ways of mobilising domestic resources for growth, African countries should put measures which develop their bond markets.

\section{References}

African Development Bank (2013) African Domestic Bond Fund, [Online], Available on < http://www.afdb.org/en/topics-andsectors/initiatives-partnerships/african-financial-markets-initiative-afmi/african-domestic-bond-fund-adbf/ > Accessed on 15 April 2013

Ahmed, S \& Mortaza, G. (2005) Inflation and Economic Growth in Bangladesh, 1981- 2005, Policy Analysis Unit (PAU) Working Paper 0604

Ahrens, R. (2002), Predicting recessions with interest rate spreads: a multicountry regime-switching analysis, Journal of International Money and Finance 21, pp.519-537.

Beck, T. (2003) Stock markets, banks, and Economic development: Theory and Evidence, EIB Papers, Vol. 8 (1)

Dahou, K., Ismael, H \& Pfister, M (2009) Deepening African Financial Markets For Growth And Investment, NEPAD-OECD Africa Investment Initiative, [Online], Available on < http://www.oecd.org/daf/inv/investmentfordevelopment/43966839.pdf >. Accessed on 20 January 2013

Dailami, M \& Atkin, M. (1990) Stock Markets in Developing Countries: Key Issues and a Research Agenda, Policy, Research, and External Affairs, WPS 515

Easterly, W. \& Levine, R. (1997) Africa's growth tragedy: Policies and ethnic divisions, Quarterly Journal of Economics 112: 1203-1250

Fink, G., Haiss, P. and Hristoforova, S. (2003) Bond Markets and Economic Growth, IEF Working Paper Nr. 49

Gamber, E.N. (1996), The Policy Content of the Yield Curve Slope, Review of Financial Economics, Vol. 5, No. 2, pp. 163-179.

Gonzalo, J., Lee, T. (1998), Pitfalls in Testing for Long Run Relationships, Journal of Econometrics 86, pp.129-154

Gujarati, D.N. (2003) Basic Econometrics, 4th Edition, McGraw-Hill, Inc. U.S.A

Harris, R.D.F. (1997) Stock markets and development: A re-assessment. European Economic Review 41: 139-146.

Harvey, C.R. (1989), Forecasts of Economic Growth from the Bond and Stock Markets, Financial Analysts Journal, September-October 1989, pp.38-45.

Harvey, C.R. (1991), Interest Rate Based Forecasts of German Economic Growth, Review of World Economics, Weltwirtschaftliches Archiv, Zeitschrift des Instituts für Weltwirtschaft Kiel, Band 127, Heft 4, pp.701-718.

Haug, A.A. (1996), Tests for Cointegration: A Monte Carlo Comparison, Journal of Econometrics 71, pp.89-115

Maana, I., Owono, R. and Mutai, N. (2008) Domestic Debt and its Impact on the Economy: The Case of Kenya, Paper Presented During the 13th Annual African Econometric Society Conference in Pretoria, South Africa from 9th to 11th July 2008.

Mallik, G \& Chowdhury, A. (2001) Inflation and Economic Growth: Evidence from Four South Asian Countries, Asia-Pacific Development Journal, 8, 1, June, 2001

Mu, Y., Phelps, P \& Stotsky, J.G (2013) Bond Markets in Africa, International Monetary Fund Working Paper Series

Said, R.M (2012) East Asian Bond Markets and Economic Growth, DOI: 10.7763/IPEDR, V57 14

The African Financial Markets Initiative (2008) Mapping of Current Ongoing Initiatives related to Bond market development in Africa, Summary of Regional Studies, African Development Bank

Van Zyl C, Botha, Z, Skerritt, P \& Goodspeed, I, (2009) Understanding South African Financial Markets, Van Schaik Publisher. South Africa. 